\title{
Perintah Atasan atau Jabatan (Ambtelijk Bevel) sebagai Penyebab Korupsi di Lingkungan Birokrasi
}

\author{
Hasbullah \\ Fakultas Hukum, Universitas Pancasila Jakarta \\ Email:hasbullah.fhup@gmail.com
}

\begin{abstract}
ABSTRAK
Korupsi di lingkungan birokrasi adalah yang tertinggi dibanding sektor lainnya. Beberapa kasus menunjukan sistem birokrasi menjadi penyebab terjadinya korupsi dilingkungan birokrasi, misalnya adanya perintah atasan untuk memotong anggaran pekerjaan pengadaan barang dan bawahan menjalankan perintah atasan tersebut sebagai bentuk tugas jabatan. menarik untuk penulis kaji adalah faktor apa saja yang menyebabkan perilaku korup pada birokrasi sering terjadi? Pertanyaan selanjutnya adalah apakah perintah atasan atau jabatan yang korupsi mengakibatkan bawahannya juga dianggap turut serta melakukan tindak pidana korupsi?, atas permasalahan tersebut kemudian penulis analisa dengan menggunakan metode penelitian normatif dan dihasilkan penelitian bahwa Tindak pidana Korupsi dalam birokrasi tidak seluruhnya faktor kesengajaan pelakunya, terdapat penggolongan birokrat yang melakukan koruspi, yaitu golongan birokrat yang sengaja melakukan korupsi dan kedua golongan birokrat karena faktor atasan atau perintah jabatannya melakukan korupsi, terhadap bawahan yang melakukan karena hanya melaksanakan perintah atasannya yang tidak dapat dia tolak, maka berlakulah penghapusan pidana terhadap bawahan yang melakukan perintah atasannya dalam kasus korupsi diatur dalam pasal 51 ayat (1). Dalam pennggulangan terhadap tindakan korupsi di lingkungan birokrasi dapat dilakukan memperbaiki penghasilan (gaji), memperbaiki manejemen birokrasi dan memperbaiki etika dan moral dengan menumbuhkan kebanggaan-kebanggaan dan atribut kehormatan diri setiap jabatan dan pekerjaan, teladan dan pelaku pimpinan atau atasan lebih efektif dalam memasyarakatkan pandangan, penilaian dan kebijakan, terbuka untuk kontrol, adanya kontrol sosial dan sanksi sosial.
\end{abstract}

Kata kunci: korupsi, melaksanakan perintah atasan

\section{PENDAHULUAN}

Negara Indonesia merupakan Negara hukum (rechstaat) sebagaimana dimaksud dalam pasal 1 ayat (3) Undang-Undang RI 1945 Perubahan Ketiga, yang menyatakan Negara Indonesia adalah negara hukum, hal ini berarti Indonesia sebagai reschtsaat, dengan menjalankan supremasi hukum, persamaan kedudukan didepan hukum dan menghormati hak asasi manusia. Atas amanat konstitusi tersebut menjelaskan bahwa cita-cita Negara hukum yang tekandung dalam UUD1945 bukanlah sekedar Negara yang berlandaskan sembarang hukum. Hukum yang didambakan bukanlah hukum yang ditetapkan semata-mata atas dasar kekuasaan, yang dapat menuju atau mencerminkan kekuasaan mutlak atau otoriter. Hukum yang demikian bukanlah hukum yang adil, yang didasarkan pada keadilan bagi rakyat sebagaimana bunyi sila kelima Pancasila. Citacita negara hukum dalam konstitusi negara Indonesia sampai dengan saat ini masih belum sepenuhnya diterapkan dalam peyelenggaraan pemerintahan negara Indonesia, hal tersebut ditandai masih banyaknya praktek-praktek korupsi, praktek korupsi mencerminkan negara berdasarkan kekuasaan dan jauh dari rasa keadilan bagi masyarakat Indonesia, bahkan korupsi sudah menjadi kebiasaan yang terjadi dalam birokrasi pemerintahan, besarnya tindak pidana korupsi dalam birokrasi pemerintahan Indonesia sebagaimana dijelaskan oleh ICW yang merilis Korupsi bidang birokrasi adalah yang tertinggi dengan 145 kasus. Berikutnya lembaga nonkementerian 8 (delapan) kasus, BUMN 7 (tujuh), KPU 7 (tujuh), kecamatan/kelurahan 7 (tujuh), universitas 6 (enam), dan DPRD 5 (lima) (“Korupsi di Birokrasi”, 2016).

Besarnya tingkat korupsi pada birokrasi sudah terjadi dari beberapa masa Presiden RI, mantan Presiden Megawati pernah mengeluhkan soal buruknya birokrasi kita,istilahnya birokrasi keranjang sampah karena perintah presiden kepada birokrasi pemerintahannya tidak dijalankan dengan baik ("Presiden Megawati", 2002). Dalam pemerintahan Susilo Bambang YudhoyonoJusuf Kalla (SBY-JK) yang menggantikannya, tentu mereka mewarisi birokrasi keranjang 
sampah. Karena itu, tekad dan gagasan SBY-JK untuk menciptakan masyarakat yang aman, adil, dan sejahtera dalam 100 hari perjalanan pemerintahannya ternyata terbentur oleh persoalan birokrasi juga sehingga koordinasi pemerintahannya tidak berjalan dengan baik, pada pemerintahan saat ini era Joko Widodo, Korupsi birokrasi belum juga terjadi penurunan, belum memuaskan dan jauh dari harapan masyarakat.

Menurut Jeremy Pope (Pope, 2008, h. 2) penyakit birokrasi tidak terlepas dari dua hal, pertama karena melemahnya nilai-nilai sosial, kepentingan pribadi menjadi lebih utama dibanding kepentingan umum, serta kepemilikan benda secara individual menjadi etika pribadi yang melandasi prilaku sosial sebagian besar orang. Kedua, tidak ada transparansi dan tanggung gugat sistem integritas publik. Birokrasi pelayanan publik justru digunakan oleh pejabat publik untuk mengejar ambisi politik pribadi, semata-mata demi promosi jabatan dan kenaikan pangkat. Sementara kualitas dan kuantitas pelayanan publik, bukan prioritas dan orientasi yang utama. Dan kedua, tidak adanya transpransi dan tanggung gugat dalam sistem integritas publik. Dari penjelasan Pompe terlihat bahwa mentalitas birokrat menjadi faktor penting perilaku korupsi terjadi di lingkungan birokrasi, namun selain yang dikemukakan pompe di atas, faktor utama terjadinya korupsi adalah faktor sistem birokrasi yang memberi kesempatan untuk korupsi, termasuk mental korup pejabat atasan yang ditularkan kepada bawahannya.

Beberapa kasus menunjukan sistem birokrasi menjadi penyebab terjadinya korupsi di lingkungan birokrasi, misalnya adanya perintah atasan untuk memotong anggaran pekerjaan pengadaan barang dan bawahan menjalankan perintah atasan tersebut sebagai bentuk tugas jabatan. Kasuskasus perintah atasan sebagai penyebab korupsi banyak terjadi di birokrasi, misalnya pada kasus pengendalian banjir Suku Dinas PU Tata Air Jakarta Barat, kasusnya berawal dari pekerjaan swakelola kurasan dan pembentukan dinding turap untuk menanggulangi banjir, dalam proyek tersebut Kepala Suku Dinas memotong 30\% dari anggaran proyek swakelola tersebut, meskipun proyek tersebut dijalankan sampai dengan selesai namun bawahan (kepala seksi) dianggap melakukan korupsi karena menjalankan proyek yang telah dipotong terlebih dahulu oleh kepala suku dinas. Dari penjelasan di atas, menarik penulis untuk di kaji dengan menjawab permasalahan yaitu faktor apa saja yang menyebabkan perilaku korupsi di lingkungan birokrasi sering terjadi? Pertanyaan selanjutnya adalah apakah perintah atasan atau jabatan yang melakukan korupsi mengakibatkan bawahannya juga dianggap turut serta melakukan tindak pidana korupsi? Kemudian permasalahan yang dibahas terakhir adalah bagaimana penanggulangan korupsi di lingkungan birokrasi?

\section{TUJUAN PENELITIAN}

Atas penjelasan latar belakang serta permasalahan di atas, penelitian ini ditujukan untuk memberikan kontribusi pemikiran dalam penanggulangan masalah korupsi di lingkungan birokrasi, dengan menjelaskan dan menganalisis:

a. Faktor-faktor yang menyebabkan perilaku korupsi di lingkungan birokrasi;

b. Pertanggungjawaban pidana atas Perintah atasan atau jabatan (Ambtelijk Bevel)dalam terjadinya tindak pidana korupsi;

c. penanggulangan tindak pidana korupsi di lingkungan birokrasi.

\section{METODE PENELITIAN}

Dalam penelitian ini dibahas berpokok pangkal pada masalah perintah atasan atau jabatan (ambtelijk bevel) sebagai penyebab korupsi di Lingkungan Birokrasi, yang diteliti dengan menggunakan bahan-bahan penulisan yang sudah tersedia (ready stock) dengan menghubungkan 
teori-teori hukum. Dengan demikian metode yang digunakan adalah pendekatan yuridis normatif yaitu penelitian dengan pendekatan konsep atau metode dalam ilmu hukum yang normatif.

Semua data yang diperoleh penulis dalam penelitian ini digolongkan menurut jenis data, sumber data dan kekuatan mengikatnya. Sesuai dengan spesifikasi penelitian tersebut di atas, maka jenis data yang digunakan dalam penelitian ini diperoleh dari kepustakaan (data sekunder). Sumber data sekunder ini diperoleh dari sumber atau bahan hukum primer, sekunder, tertier.

a. Bahan Hukum Primer meliputi, Undang-Undang Tindak pidana Korupsi, KUHP, KUHAP.

b. Bahan Hukum Sekunder, yaitu segala hal yang memberikan penjelasan mengenai bahan hukum primer, seperti rancangan undang-undang, buku-buku, hasil-hasil penelitian, surat kabar, majalah-majalah, laporan-laporan yang berkaitan dengan materi bahan penulisan hukum ini.

c. Bahan Hukum Tertier, yaitu bahan yang memberikan petunjuk maupun penjelasan terhadap bahan hukum primer dan sekunder, seperti kamus dan ensiklopedi.

Data yang berhasil dikumpulkan akan diuraikan secara sistematis. Data yang diperoleh tersebut kemudian dianalisa secara normatif dan komparatif dengan penguraian secara deskriptif analitis dan preskriptif dalam arti menggambarkan data apa adanya dan memberikan pemikiranpemikiran untuk masa yang akan datang. Hasil penelitian ini akan disajikan dalam bentuk narasi.

\section{HASIL DAN PEMBAHASAN Korupsi di lingkungan birokrasi}

Menurut Fockema Andreae, dalam buku Andi Hamzah disebutkan kata "korupsi" berasal dari bahasa latin yaitu "corruptio atau corruptus". Namun kata "corruptio" itu berasal pula dari kata asal "corrumpere", yaitu suatu kata dalam bahasa latin yang lebih tua. Dari bahasa latin ini kemudian turun ke banyak bahasa Eropa seperti Inggris yaitu corruption, Prancis yaitu corruption, Belanda yaitu corruptie. (Andi Hamzah,2008:4) Arti harfiah dari kata itu adalah kebusukan, tidak bermoral, penyimpangan dari kesucian, dapat disuap yang menghina atau memfitnah seperti dapat dibaca dlam The Lexicon Webster Dictionary:

"Corruption (L.Corruptio (n-)) the act of corrupting or the state of being corrupt; putrafactive decomposition, putrid matter, moral pervension;devarpity, pervension of integrity;corrupt or dishonest proceeding, bribery, perversion from a state of purity; debasement, as of a languange, a debased form of a word" (the lexicon 1978).

Black's Law Dictionary juga mengungkapkan mengenai Pengertian Korupsi, Korupsi merupakan suatu perbuatan yang dilakukan dengan maksud untuk memberikan keuntungan yang tidak resmi dengan mempergunakan hak-hak dari pihak lain, yang secara salah dalam menggunakan jabatannya atau karakternya di dalam memperoleh suatu keuntungan untuk dirinya sendiri atau orang lain, yang berlawanan dengan kewajibannya dan juga hak-hak dari pihak lain.

Dari pengertian korupsi yang dipaparkan di atas, maka dapat disimpulkanbahwa pengertian Korupsi adalah perbuatan yang buruk seperti penggelapan uang, penerimaan uang sogok dan lain sebagainya untuk memperkaya diri sendiri atau orang lain atau korporasi, yang mengakibatkan kerugian keuangan pada negara (Hamzah, 2008, h. 12).

Pengertian dari beberapa pandangan itulah yang kemudian dikenal di Indonesia dengan nama korupsi yang diatur dalam Undang-Undang No.31 Tahun 1999 tentang pemberantasan tindak pidana korupsi yang kemudian diubah dengan Undang-Undang No. 20 tahun 2001, dalam undang-undang tersebut pengertian korupsi tidak didefinisikan sebagaiamana nomanklatur pidana pada umumnya, namun korupsi dalam undang-undang tersebut dikriminalisasikan sebagai berikut: 
a. Korupsi yang terkait dengan kerugian keuangan negara: Pasal 2 ayat (1) dan Pasal 3

b. Korupsi yang terkait dengan suap-menyuap, Pasal 5 ayat 1 huruf a, Pasal 5 ayat 1 huruf b, Pasal 5 ayat 2, Pasal 6 ayat (1) huruf a, Pasal 6 ayat (1) huruf b, Pasal 11, Pasal 12 huruf a, Pasal 12 huruf b, Pasal 12 huruf c, Pasal 12 huruf d, Pasal 13, Perbuatan Curang, Pasal 7 ayat (1) huruf a, Pasal 7 ayat (1) huruf b, Pasal 7 ayat (1) huruf c, Pasal 7 ayat (1) huruf d, Pasal 7 ayat (2), Pasal 12 huruf h.

c. Korupsi terkait dengan Penggelapan dalam Jabatan: Pasal 8, Pasal 9, Pasal 10 huruf a, Pasal 10 huruf b, Pasal 10 huruf c, Pemerasan atau Meminta karena Jabatan, Pasal 12 huruf e, Pasal 12 huruf f, Pasal 12 huruf g, Korupsi yang terkait dengan benturan kepentingan dalam pengadaan, Pasal 12 huruf i, Korupsi yang terkait dengan gratifikasi, Pasal 12 B ayat (1) jo. Pasal $12 \mathrm{C}$.

Pengaturan tentang korupsi di Indonesia berbeda dengan pengaturan korupsi di Internasional, konvensi internasional tentang korupsi, memandang bahwa korupsi dapat dikenakan tidak hanya korupsi di lingkungan pemerintahan namun korupsi dalam lingkungan swasta juga dianggap sebagai korupsi, hal terebut terlihat dalam pasal 21 United Nations Convention Against Corruption.

Pengaturan korupsi di Indonesia terlihat ditujukan fokus terhadap penyalahgunaan kewenangan serta kerugian keuangan negara dalam pemerintahan, hal tersebut dilandasi banyaknya praktek korupsi dalam lingkungan birokrasi Indonesia. Korupsi yang terjadi di lingkungan birokrasi publik merupakan gejala yang komplek yang didorong oleh berbagai faktor yang saling terkait satu sama lain, karena itu korupsi disebut sebagai 'multi-faceted social problems'. Dari berbagai faktor penyebab korupsi pada dasarnya dapat dikelompokkan menjadi penyebab kultural, struktural, dan individual.

Birokrasi Menurut Sedarmayanti (Sedarmayanti, 2009, h. 67) merupakan sistem penyelenggaraan pemerintahan yang dijalankan pegawai negeri berdasarkan peraturan perundang-undangan. Birokrasi adalah struktur organisasi digambarkan dengan hierarki yang pejabatnya di angkat atau di tunjuk, garis tanggung jawab dan kewenangannya diatur oleh 9 peraturan yang diketahui (termasuk sebelumnya), dan justifikasi setiap keputusan membutuhkan referensi untuk mengetahui kebijakan yang pengesahannya ditentukan oleh pemberi mandat di luar struktur organisasi itu sendiri. Lebih rinci lagi birokrasi dijabarkan sebagai organisasi yang memiliki jenjang, setiap jenjang diduduki oleh pejabat yang ditunjuk/diangkat, disertai aturan tentanng kewenangan dan tanggung jawabnya, dan setiap kebijakan yang dibuat harus diketahui oleh pemberi mandat. Istilah birokrasi pertama kali dikemukakan oleh Martin Albrow untuk memberikan atribut terhadap istilah yang dipergunakan oleh seorang phsyiocrat Perancis Vincent de Gourney yang untuk pertama kalinya memakai istilah birokrasi dalam menguraikan sistem Pemerintahan Prusia di tahun 1745 (Thoha, 2003, h. 920)

Berdasarkan pengertian birokrasi di atas menunjukan bahwa birokrasi merupakan kegiatan manejemen yang baik dan terstruktur, Namun, kata "birokrasi," kini seringkali dipersepsikan masyarakat sebagai gambaran buram mengenai prosedur kerja yang berbelit-belit, proses pelayanan yang lamban, mekanisme kerja yang tidak efisien dan kurang efektif, sumber korupsi dan penyalahgunaan wewenang dan semacamnya. Jika di masa lalu korupsi sering diidentikkan dengan pejabat atau pegawai negeri yang telah menyalahgunakan keuangan negara maka dalam perkembangannya saat ini masalah korupsi juga telah melibatkan birokrat di administrasi. Saat ini, fakta yang ditampilkan melalui berbagai media massa menunjukkan masih banyak ditemukan fenomena atau gejala yang menggambarkan praktek korupsi di birokrasi yang 
semakin luas. Indonesia mengalami krisis kepercayaan masyarakat pada birokrasi dalam memberikan pelayanan publik yang bersih dari berbagai macam tindakan korupsi. Meluasnya praktik KKN (kolusi, korupsi, dan nepotisme) dalam tubuh birokrasi publik semakin memudarkan upaya perbaikan birokrasi itu sendiri. Praktik KKN telah melahirkan pelayanan publik yang bersifat diskriminatif, karena pelayanan hanya diberikan kepada mereka yang mampu membayar. Dapat dikatakan bahwa dalam bertindak para birokrat tidak berdasarkan kaidah etis yang ada.

Beberapa pengamat, seperti Karl D. Jackson menilai bahwa birokrasi di Indonesia adalah model bureaucratic polity dimana terjadi akumulasi kekuasaan pada negara dan menyingkirkan peran masyarakat dari ruang politik dan pemerintahan. Sementara Richard Robinson dan King menyebut birokrasi di Indonesia sebagai bureaucratic capitalism. Sedangkan Hans Dieter Evers melihat bahwa proses birokrasi di Indonesia berkembang model birokrasi ala Parkinson dan Orwel. Birokrasi ala Parkinson adalah pola dimana terjadi proses pertumbuhan jumlah personil dan pemekaran struktural dalam birokrasi secara tidak terkendali. Sedang birokrasi ala Orwel adalah pola birokrasi sebagai proses perluasan kekuasaaan pemerintah dengan 6 maksud mengontrol kegiatan ekonomi, politik dan sosial dengan peraturan, regulasi dan bila perlu melalui paksaaan (Romli, 2007, h. 132)

\section{Faktor penyebab dan penanggulangan korupsi di lingkungan birokrasi}

Ada beberapa sebab terjadinya praktek korupsi di lingkungan Birokrasi sebagai berikut (Hamzah, 2008, h. 13):

1. Gaji Pegawai Negeri yang rendah, kurang sempurnanya peraturan perundangundangan,administrasi yang lamban dan sebagainya. Pada umumnya orang menghubungkan tumbuh subumya korupsi disebabkan karena kurangnya gaji, buruknya perekonomian, mental pejabat yang kurang baik, administrasi dan managemen yang kacau. Kurangnya gaji dan pendapatan pegawai negeri memang faktor yang paling menonjol dalam arti merata dan meluasnya korupsi di Indonesia. Hal ini dikemukakan oleh Guy J.Pauker dalam tulisannya berjudul "indonesia 1979: the record of three decade" (Asia Survey Vol.XX No.2,1980:13:

"although corruption is widespread in indonesia as a means of supplementing excessively low goverment salaries, the resources of the nations are not being used praimarly for the accumulation of vast private fortunes, but for economic development and to some extent for welfare"

2. Kultur (budaya), korupsi karena kultur adalah dalam hubungan meluasnya korupsi di Indonesia. Budaya pemberian hadiah, ucapan terima kasih yang sudah menjadi budaya rakyat Indonesia mengakibatkan semakin suburnya budaya korupsi di Indonesia. Korupsi di lingkungan birokrasi saat ini dianggap sudah membudaya dan menjadi bagian yang tidak dapat dipisahkan dari praktek kehidupan masyarakat sehari-hari. Soedarso (Soedarso, 1969, h. 14) yang menunjuk beberapa penyebab korupsi, selanjutnya menguraikan tetntang latar belakang kultur, antara lain dikatakan:"dalam hubungan meluasnya korupsi di Indonesia, apabila ditinjau lebih lanjut mungkin kita dapat menelurkan korupsi sebagai way of life dari banyak orang, mengapa korupsi itu secara diam-diam di tolereer, bukan oleh penguasa tetapi oleh masyarakat itu sendiri."

3. Kurangnya manajemen dan sistem birokrasi sebagai penyebab korupsi. Manajemen dan sistem yang kurang baik dapat menimbulkan kebocoran-kebocoran keuangan yang membawa akibat mempermudah orang melakukan korupsi. Sistem birokrasi yang berjenjang dan tidak terkontrol dengan baik menjadi penyebab utama tindak pidana korupsi terjadi, biasanya suatu korupsi yang terjadi dalam lingkungan birokrasi dimulai dari niat atasannya yang kemudian dijalankan bawahannya. Proyek pengadaan barang menjadi perbuatan yang palin banyak terjadi korupsi secara sistematis, seperti penentuan pemenang lelang yang diarahkan oleh atasannya, 
mengakibatkan bawahan tidak bisa menolak atas arahan atasannya tersebut. Kasus lain mengani proyek pengadaan swakelola yang sering terjadinya pemotongan dana yang diarahkan oleh atasannya.

\section{Korupsi sebagai menjalankan perintah atasan (jabatan) menurut hukum pidana}

Sejumlah kasus yang disidangkan di Pengadilan Tindak Pidana Korupsi, terdakwa sering berdalih hanya melaksanakan perintah dalam jabatannya, atau melaksanakan perintah atasan. Contoh kasus tentang perintah atasan dalam melakukan tindak pidana korupsi sedang terjadi pada Tindak Pidana Korupsi Penyalahgunaan Dana Kegiatan Swakelola pada Suku Dinas Pekerjaan Umum Tata Air Kota Administrasi Jakarta Barat Tahun Anggaran 2013-2014, kasus terebut adanya bermula dari kegiatan pekerjaan swakelola di Suku Dinas Pekerjaan Umum Tata Air Jakarta Barat Tahun anggaran 2013. Ada empat pekerjaan senilai kurang lebih Rp 66.649.311.310 berupa pemeliharaan Infrastruktur saluran lokal, pemeliharaan saluran drainase jalan, pengerukan dan perbaikan saluran penghubung, dan refungsionalisasi sungai/kali dan penghubung. Dalam pelaksanaannya diduga tidak sesuai dengan laporan pertanggungjawaban kegiatan maupun laporan keuangan karena ada pemalsuan-pemalsuan dokumen didalam kedua laporan yang seolah-olah telah dilaksanakan oleh pihak ketiga (fiktif). Jumlah kerugian negara dalam perkara ini, yakni sebesar Rp 43.000.000.000,-, dalam keterangan di persidangan kasus korupsi tersebut dilakukan sebagai berikut:

a. Kepala Suku Dinas PU Tata Air sebagai Kuasa Pengguna Anggaran memerintahkan untuk melaksanakan proyek normaliasi sungai untuk menanggulangi banjir, dan memerintahkan kepada Kepala Seksi Pemeliharaan membuat SPT kepada Kasi Kecamatan, kemudian diperintahkan setiap anggaran SPT dipotong 30\% untuk dibagi-bagikan kepada bendahara dll b. SPT yang diberikan kepada Kasi Kecamatan untuk melaksanakan normalisasi tersebut dicairkan oleh Bendhra hanya 70\% dri total biaya yang tercantum dalam SPT;

c. Kemudian Kasi Kecamatan diarahkan untuk tidak perlu membuat surat pertanggungjawban, karena SPJ dibuat oleh Kasi Pemeliharan dengan kuitansi fiktif dan dicocokan dengan RAB

d. Kasi Kecanatan sebagai bawahan tetap melaksanakan normalisasi sungai tersebut dan pekerjaan selesai

Pada kasus di atas terlihat sistem birokrasi yang mengakibatkan Kepala Seksi ikut terlibat dalam perbuatan korupsi yang diawali dari atasannya. Terhadap kasus tersebut PN Tipikor memvonis Kasudin dan para Kasinya terbukti melakukan tindak pidana Korupsi seara bersama-sama. Namun jika kita kaitkan dengan teori melaskanakan perintah atasan sehingga dapat dibebaskan beredasarkan pasal 51 ayat (1) KUHP, pasal tersebut banyak diterpkan pada beberapa kasus bebasnya terdakwa dengan alasan melaksanakan perintah atasan atau jabatan, antara lain:

1. Putusan MA No. 194/PK/Pid.Sus/2010atas nama Syamsul Bahri, Dalam kasus Syamsul Bahri, majelis PK melihat semua perbuatan terdakwa dilakukan atas perintah Bupati Jeneponto yang sah. Bupati memerintahkan terdakwa menyimpan buku rekening dana proyek Program Penanggulangan Dampak Pengurangan Subsidi Energi Bidang Kesehatan (PD PSE-BK) yang kemudian berubah menjadi Program Kompensasi Pengurangan Subsidi Bahan Bakar Minyak Bidang Kesehatan PKPS BBM-BK). Penggunaan anggaran bantuan orang miskin untuk pembelian ambulance juga atas perintah Bupati Jeneponto. Kalaupun terdakwa hendak dimintai tanggung jawab, ternyata terdakwa bukan orang yang punya kewenangan menentukan. Terdakwa hanya sebagai Kepala Bagian Keuangan Pemkab Jeneponto, bukan sebagai pengelola proyek PKPS BBM-BK. "Penggunaan uang dalam rekening tersebut semuanya adalah atas perintah dari bupatiKarena itu sebagai bawahan terdakwa tidak mempunyai pilihan untuk menolak" 
2. Putusan Mahkamah Agung Nomor 685K/PID/2005 Tahun 2005 atas nama terdakwa Drs. H. ABDUL SHOBUR, SH.MM, Majelis hakim menilai Shobur terbukti mengirim surat itu. Namun, pengiriman surat itu dilakukan sesuai dengan perintah atasannya sehingga tindakannya ini tidak memenuhi unsur tindak pidana korupsi.

Dari kedua putusan di atas tergambar bahwa penyebab terjadinya korupsi karena manejemen birokrasi dan sistem yang mengakibatkan terjadinya korupsi, namun terhadap bawahan yang menjalankan perintah atasan dapat dijadikan alasan dibebaskannya Terdakwa.

Melaksanakan perintah jabatan merupakan salah satu alasan menghapus pidana yang dikenal dalam KUHP. Alasan penghapus pidana dalam KUHP meliputi alasan pembenar (rechtvaardigingsgrond) dan alasan pemaaf (schulduitsluitingsgrond). 'Melaksanakan perintah jabatan' termasuk bagian dari alasan pembenar. Alasan lainnya adalah keadaan darurat (noodtoestand), pembelaan terpaksa (noodweer), dan melaksanakan perintah undang-undang. Alasan penghapus pidana juga dikenal dalam perundang-undangan di luar KUHP.

Rumusan tentang 'perintah jabatan' (ambtelijk bevel) diatur dalam pasal 51 KUHP, yang berbunyi sebagai berikut:

(1) Pasal ini menyebutkan barang siapa melakukan perbuatan untuk melaksanakan perintah jabatan yang diberikan oleh penguasa yang berwenang, tidak dipidana.

(2) Perintah jabatan tanpa wewenang tidak menyebabkan hapusnya pidana kecuali jika yang diperintah, dengan iktikad baik mengira bahwa perintah diberikan dengan wewenang dan pelaksanaannya termasuk dalam lingkungan pekerjaannya.

Pengertian 'perintah' dalam pasal 51 KUHP maksudnya berdasarkan putusan Hoge Raad 17 Desember 1899 No. 6603, ( E. Utrecht,1958: 351) berpendapat perintah di sini bukan saja perintah dalam arti konkrit, tetapi juga suatu instruksi yang bersifat umum.Perintah jabatan atau ambtelijk bevel dapat diartikan sebagai suatu perintah yang telah diberikan oleh seorang atasan, dimana kewenangan untuk memerintah semacam itu bersumber pada suatu ambtelijke positie atau suatu kedudukan menurut jabatan, baik dari orang yang memberikan perintah maupun dari orang yang menerima perintah (Lamintang, 1984, h. 500).

Menurut Andi Hamzah (1994, h. 163), perintah itu diberikan karena jabatan. Jadi, antara yang memberi perintah dan orang yang diperintah ada hubungan hukum publik. Perintah yang diberikan pejabat pekerjaan umum kepada pemborong berdasarkan hukum perjanjian tidak masuk kategori 'perintah jabatan'. Menurut Sianturi (1996, h. 290), hubungan hukum itu harus menurut hukum publik. Posisi pemberi perintah harus didasarkan pada ketentuan-ketentuan dari hukum publik. Ada tiga syarat yang harus dipenuhi agar bisa disebut perintah jabatan, yakni (i) ada hubungan antara pemberi perintah dengan pelaksana perintah berdasarkan hukum publik; (ii) kewenangan pemberi perintah harus sesuai dengan jabatannya berdasarkan hukum publik tersebut; dan (iii) perintah yang diberikan itu termasuk dalam lingkungan kewenangan jabatannya.

Apakah hubungan hukum itu harus atasan dengan bawahan (ondergeschiktheid) dalam hubungan kepegawaian, misalnya dekan memberi perintah kepada pembantu dekan? Utrecht (1958, h. 378) menulis baik yang memerintah maupun yang diperintah tidak perlu berstatus pegawai negeri. 'Ambtelijk' hanya berarti saja suatu hubungan menurut hukum publik. Tidak perlu juga secara hierarkis yang diperintah berada di bawah pemberi perintah. Dalam hal ini Prodjodikoro (1989, h. 87-8) berpendapat dianggap suatu perintah yakni suatu instruksi dari seorang atasan kepada semua orang bawahan tanpa menyebutkan nama orang-orang tertentu, untuk melakukan hal-hal yang tanpa instruksi itu merupakan tindak pidana. Tetapi perintah seorang polisi kepada pekerja swasta untuk membersihkan jalan yang menghalangi lalu lintas termasuk lingkup perintah yang 
dilindungi pasal 51 ayat (1) KUHP meskipun antara polisi dan swasta tadi bukan atasanbawahan.

Cara dan alat yang dipakai untuk melaksanakan perintah jabatan harus sesuai. Contohnya, seorang penjual rokok tidak boleh mendapat perintah dari polisi untuk menahan seorang tersangka. Ketidaksesuaian antara perintah dengan pekerjaan dapat menyebabkan seseorang tak bisa berlindung di balik pasal 51 ayat (1) KUHP. Contohnya putusan MA No. 166 K/Kr/1963 yang menyebutkan perintah dari ketua pengadilan kepada panitera mengenai hal di luar lingkup pekerjaan si panitera bukan perintah sebagaimana dimaksud pasal 51 ayat (1) KUHP (Soerodibroto, 2003, h. 46).

Tentang alat dan cara perintah disampaikan, Jan Remmelink (2003, h. 254) berpendapat perintah tersebut tidak perlu langsung diterima oleh penerima perintah. Sarana komunikasi yang biasa dipakai, termasuk sarana bantu lainya, juga dapat dipergunakan untuk menyampaikan perintah tersebut. Konteks ini berhubungan dengan konsep pendelegasian wewenang. Menurut konsep ini, si A, berdasarkan mandat yang diterimanya dari B selaku pejabat yang berwenang, dimungkinkan mengeluarkan perintah kepada orang lain atas nama $\mathrm{B}$.

Kewenangan penguasa menjadi faktor lain yang harus dipertimbangkan. Artinya, pemberi perintah haruslah orang yang punya kewenangan (l'autorite legitime). Karena itu ayat (2) pasal 51 KUHP menyebut perintah jabatan yang diberikan tanpa kewenangan tidak menghapuskan pidana. Dengan demikian, penerima dan pelaksana perintah harus mengetahui bahwa perintah yang ia terima diberikan oleh pejabat yang berwenang, dan perintah itu termasuk lingkup wewenang pejabat dimaksud. Pengertian pelaksana perintah "harus mengetahui" dalam konteks ini, kata S.R. Sianturi (1996, h. 291) bermakna luas, yaitu menurut perhitungan yang layak atau menurut perhitungan umum ia seharusnya mengetahui.

Dengan demikian, ada dua syarat yang harus dipenuhi agar seorang pelaksana perintah lolos dari jerat pidana (Andi Hamzah mengutip Vos, 1994, h. 163; Bambang Poernomo, 1994, h. 201), yaitu:

(i) syarat subjektif, pembuat harus dengan iktikad baik memandang bahwa perintah itu datang dari yang berwenang, terlihat dalam kasus Putusan MA No. 194/PK/Pid.Sus/2010atas nama Syamsul Bahri, perbuatan terdakwa dilakukan atas perintah Bupati Jeneponto yang sah yang mempunyai kewenangan untuk menyimpan buku rekening dana proyek Program Penanggulangan Dampak Pengurangan Subsidi Energi Bidang Kesehatan (PD PSE-BK) yang kemudian berubah menjadi Program Kompensasi Pengurangan Subsidi Bahan Bakar Minyak Bidang Kesehatan PKPS BBM-BK); dan

(ii) syarat objektif, pelaksanaan perintah harus terletak dalam lingkup pembuat sebagai bawahan. Jadi pada Putusan MA No. 194/PK/Pid.Sus/2010atas nama Syamsul Bahri, terdakwa bukan orang yang punya kewenangan menentukan. Terdakwa hanya sebagai Kepala Bagian Keuangan Pemkab Jeneponto, bukan sebagai pengelola proyek PKPS BBM-BK. "Penggunaan uang dalam rekening tersebut semuanya adalah atas perintah dari bupati. Bagi Andi Hamzah, pasal 51 ayat (1) adalah alasan pembenar karena unsur melawan hukum tidak ada, sedangkan pasal 51 ayat (1) adalah alasan pemaaf karena perbuatan tetap melawan hukum hanya pelaku tidak bersalah karena ia beriktikad baik menjalankan perintah pejabat yang berwenang padahal sebenarnya tidak. 


\section{Penanggulangan tindak pidana korupsi di lingkungan birokrasi}

Penanggulangan tindak pidana korupsi di lingkungan Birokrasi harus dilaksanakan secara komprehensif dan sesuai dengan penyebab korupsi itu sendiri, penyebab korupsi paling dominan yaitu dari mentalitas birokrat yang bersumber dari atasannya, ketika atasan birokrat itu melakukan korupsi maka bawahannya akan ikut melakukan korupsi baik memang bawahannya sengaja korupsi atau karena faktor melaksanakan perintah atasan.

Khusus terhadap bawahan yang melaksanakan perintah atasannya maka berlakulah pasal 51 ayat (1) sebagaimana dijelaskan diatas, namun terhadap birokrat yang sengaja melakukan korupsi maka perlu penanggulangan yang komprehensif misalnya melalui pendekatan Preventif dan represif. Pendekatan preventif dapat dilakukan melaui perbaikan etika dan moral birokrat. Menurut Perspektif Etika atau Moral, korupsi terjadi bukan karena faktor ekonomi, tetapi karena mentalitas pelakunya. Korupsi birokratis bersumber dari unsur manusia atau nilai-nilai moral yang dianut masyarakatnya. Walaupun sistem pemerintahan sudah relatif baik, tetapi jika individu pelaksana dari sistem tersebut tidak dijiwai oleh nilai-nilai integritas, kejujuran, dan harkat kemanusiaan, maka sistem yang baik tersebut tidak akan efektif mencegah perilaku korup. Pelaku dan penyebar korupsi menurut perspektif ini adalah homo venalis, yaitu orang-orang yang berjiwa korup dan lebih sering menggunakan cara-cara korup dalam kehidupannya.

Korupsi tidak dapat dibiarkan berjalan begitu saja kalau suatu negara ingin mencapai tujuannya, karena kalau dibiarkan secara terus menerus, maka akan terbiasa dan menjadi subur dan akan menimbulkan sikap mental pejabat yang selalu mencari jalan pintas yang mudah dan menghalalkan segala cara (the end justifies the means). Untuk itu, korupsi perlu ditangani secara tuntas dan bertanggung jawab. Ada beberapa upaya penggulangan korupsi yang ditawarkan para ahli yang masing-masing memandang dari berbagai segi dan pandangan. langkah-langkah untuk menanggulangi korupsi sebagai berikut:

1.Membenarkan transaksi yang dahulunya dilarang dengan menentukan sejumlah pembayaran tertentu.

2.Membuat struktur baru yang mendasarkan bagaimana keputusan dibuat.

3.Melakukan perubahan organisasi yang akan mempermudah masalah pengawasan dan pencegahan kekuasaan yang terpusat, rotasi penugasan.

Wewenang yang saling tindih organisasi yang sama, birokrasi yang saling bersaing, dan penunjukan instansi pengawas adalah saran-saran yang secara jelas diketemukan untuk mengurangi kesempatan korupsi. Dorongan untuk korupsi dapat dikurangi dengan jalan meningkatkan ancaman. Korupsi adalah persoalan nilai. Nampaknya tidak mungkin keseluruhan korupsi dibatasi, tetapi memang harus ditekan seminimum mungkin, agar beban korupsi organisasional maupun korupsi sestimik tidak terlalu besar sekiranya ada sesuatu pembaharuan struktural, barangkali mungkin untuk mengurangi kesempatan dan dorongan untuk korupsi dengan adanya perubahan organisasi.

Satu hal yang sangat penting untuk diaplikasikan dalam menangani maraknya tindakan korupsi di lingkungan birokrasi yaitu menerapkan konsep etika administrasi dan pengawasan melekat dalam lingkungan birokrasi. Etika administrasi menjadi semakin penting ketika sistem administrasi sendiri memberikan tempat bagi adanya korupsi, campur tangan politik atas birokrasi dan sebagainya. Rendahnya etika para birokrat terjadi karena rendahnya pemahaman dari norma-norma umum yang sangat mendasar tersebut. Sehubungan dengan korupsi, etika kemudian lahir sebagai alat kontrol dalam menjalankan administrasi. Hal ini dikarenakan ada seperangkat nilai yang kemudian diyakini bahkan diamanahkan kepada pemerintah untuk 
dipegang teguh dalam setiap tingkah laku administrasi. Jika etika yang kemudian dilembagakan dalam kode etik dipegang dengan teguh, maka penyimpangan seperti korupsi tidak akan terjadi.

Contoh dapat dilakukan dengan menetapkan kode etik birokrat yang merupakan norma-norma sebagai pedoman sikap, tingkah laku dan perbuatan birokrat yang diharapkan dan dipertangung jawabkan dalam melaksanakan tugas pengabdiannya kepada bangsa, negara dan masyarakat dan tugas-tugas kedinasan, organisasinya serta pergaulan hidup sehari-hari sesama birokrat dan individu-individu di dalam masyarakat. Jadi dapat disimpulkan bahwa penerapan etika dalam lingkungan birokrasi sangat penting peranannya dalam menangani tindakan korupsi ini. Berikut adalah tindakan preventif dan represif yang dapat diaplikasikan terkait dalam membangun etika birokrat yang baik.

\section{Preventif}

-Mengusahakan perbaikan penghasilan (gaji) bagi pejabat dan pegawai negeri sesuai dengan kemajuan ekonomi dan kemajuan swasta, agar pejabat dan pegawai saling menegakan wibawa dan integritas jabatannya dan tidak terbawa oleh godaan dan kesempatan yang diberikan oleh wewenangnya.

-Membangun dan menyebarkan etos pejabat dan pegawai baik di instansi pemerintah maupun swasta tentang pemisahan yang jelas dan tajam antara milik pribadi dan milik perusahaan atau milik negara.

-Menumbuhkan kebanggaan-kebanggaan dan atribut kehormatan diri setiap jabatan dan pekerjaan. Kebijakan pejabat dan pegawai bukanlah bahwa mereka kaya dan melimpah, akan tetapi mereka terhormat karena jasa pelayanannya kepada masyarakat dan negara.

-Bahwa teladan dan pelaku pimpinan dan atasan lebih efektif dalam memasyarakatkan pandangan, penilaian dan kebijakan.

-Menumbuhkan pemahaman dan kebudayaan politik yang terbuka untuk kontrol, koreksi dan peringatan, sebab wewenang dan kekuasaan itu cenderung disalahgunakan.

-Hal yang tidak kalah pentingnya adalah bagaimana menumbuhkan "sense of belongingness" dikalangan pejabat dan pegawai, sehingga mereka merasa peruasahaan tersebut adalah milik sendiri dan tidak perlu korupsi, dan selalu berusaha berbuat yang terbaik.

\section{Represif}

-Pelaporan terjadwal dan terstruktur mengenai kekayaan pejabat

-Penindakan pemidanaan dengan hukuman yang berat terhadap pelaku tindak pidana korupsi

\section{KESIMPULAN}

Tindak pidana Korupsi di lingkungan birokrasi tidak seluruhnya disebabkan oleh faktor kesengajaan birokratnya, terdapat penggolongan birokrat yang melakukan korupsi, yaitu golongan birokrat yang sengaja melakukan korupsi (pejabat atasan) dan kedua golongan birokrat karena faktor atasan atau perintah jabatannya melakukan korupsi atau disebut bawahan, sehingga pemidanaan atau hukuman terhadap bawahan yang melakukan korupsi harus dilihat apakah memang bawahan tersebut sengaja melakukan korupsi atau hanya melaksanakan perintah atasannya yang tidak dapat dia tolak, jika karena perintah atasan maka berlakulah penghapusan pidana terhadap bawahan yang melakukan perintah atasannya dalam kasus korupsi yang diatur dalam pasal 51 ayat (1) KUHP, sehingga demi kepastian hukum bawahan yang dimaksud pasal tersebut harus dibebaskan. Dalam penaggulangan terhadap tindakan korupsi di lingkungan birokrasi dapat dilakukan memperbaiki penghasilan (gaji), memperbaiki manejemen birokrasi dan memperbaiki etika dan moral dengan menumbuhkan kebanggaan-kebanggaan dan atribut kehormatan diri setiap jabatan dan pekerjaan, teladan dan pelaku pimpinan atau atasan lebih 
efektif dalam memasyarakatkan pandangan, penilaian dan kebijakan, terbuka untuk kontrol, adanya kontrol sosial dan sanksi sosial, Menumbuhkan rasa "sense of belongingness" diantara para pejabat dan pegawai. Sedangkan tindakan yang bersifat represif adalah menegakan hukum yang berlaku pada koruptor pelaporan kekayaan pejabat dan pegawai.atas dasar kesimpulan penelitian tersebut, penulis merekomendasikan atas permasalah di atas sebagai berikut:

1. Agar terhadap pemerintah (kementrian Aparatur Negara) dapat mengeluarkan regulasi tentang kode etik dan pengawasan melekat kepada Pegawai Negeri Sipil yang mengatur kewajibankewajiban Pegawai Negeri Sipil, pengawasan dan sanksi yang menyangkut etika Pegawai Negeri Sipil, khusunya terhadap atasan PNS dilakukan perekrutan yang ketat serta pembinaan yang terukur dan terarah, serta memperhatikan kesejahteraan PNS

2. Agar terhadap penegak hukum (Penyidik, Jaksa, Hakim) terhadap pelaku tindak pidana korupsi menerapkan pemidanaan sesuai dengan perturan perundang-undangan dan mempertimbangkan peran serta kesengajaan pelaku tindak pidana korupsi di lingkungan birokrasi.

\section{REFERENSI}

Darmawan, C. (2006). Transparansi birokrasi menuju birokrasi yang sehat. Bandung: PKPPW Univ. Padjadjaran.

Hamzah, A. (1994). Azas azas hukum pidana, cet 2. Jakarta: Rineka Cipta.

. (2008). Pemberantasan korupsi melalui pidana nasional dan internasional; edisi revisi 2017. Jakarta: Raja Grafindo Persada.

Lamintang P.A.F (1984). Dasar-dasar hukum pidana Indonesia. Bandung: Sinar Baru.

Pope, J. (2008). Strategi Memberantas Korupsi. Transparency International Indonesia, Jakarta. Prodjodikoro (1989). Asas-Asas Hukum Pidana Di Indonesia. Bandung: Eresco.

Romli, L. (2007). Potret otonomi daerah dan wakil rakyat di tingkat lokal. Yogyakarta: Pustaka Pelajar.

Sedarmayanti (2009). Sumber daya manusia dan produktivitas kerja. Bandung: Mandar Maju.

Soedarso, B. (1969). Korupsi di Indonesia. Jakarta: Bharata.

Sianturi, S.R., (1996). Asas-asas hukum pidana di Indonesia dan penerapannya. Alumni AhaemPatahaem. Jakarta.

Soerodibroto, R. S. (2003). KUHP dan KUHAP. Jakarta: Rajawali Pers.

Thoha, M. (2003). Kepemimpinan dalam manajemen. Jakarta: Raja Grafindo Persada.

Utrecht, E..(1958). Hukum pidana I. Bandung: Universitas Padjajaran.

"Korupsi di Birokrasi Daerah Tempatkan Posisi Tertinggi" (2016, 29 Agustus), diunduh dari http://radarpolitik.com/korupsi-di-birokrasi-daerah-tempatkan-posisi-tertinggi.

"Presiden Megawati: Pemerintah ini Keranjang Sampah" (2002, 11 Februari), diunduh dari https://m.tempo.co/read/news/2002/02/11/0552949/presiden-megawati-pemerintah-inikeranjang-sampah.

Undang-Undang No.1 tahun 1946 tentang Kitab Undang-Undang Hukum Pidana.

Undang-Undang No.8 tahun 1981 tentang KUHAP.

Undang-Undang No.31 tahun 1999 tentang Pemberantasan Tindak pidana Korupsi.

Undang-Undang No.20 tahun 2001 tentang Perubahan Undang-Undang No. 31 tahun 1999 tentang Pemberantasan Tindak pidana Korupsi. 